\title{
Positive psychology in students' axiological choice situations
}

\author{
Zinaida Brizhak $^{1, *}$, Karina Kolesina ${ }^{2}$ and Natalya Mironenkova ${ }^{3}$ \\ ${ }^{1}$ Rostov State Medical University, Nahichevansky av., 29, Rostov-on-Don, Russia \\ ${ }^{2}$ Southern Federal University, Bolshaya Sadovaya 105/42, Rostov-on-Don, Russia \\ ${ }^{3}$ Platov South-Russian State Polytechnic University, Prosveshcheniya, 132, Novocherkassk, Russia
}

\begin{abstract}
The authors define axiological choice as a touch point between the culture senses and the student's senses. This touch enables to transform students' sense predilection. However, according to the multiple nature and character of choice, the latter has a negative side, which is sacrificing one alternative in favor of some other one. Hence it makes sense to apply the positive psychology concept in modelling students' axiological choice situations. Positive psychology technologies and strategies lend "positive" support in decision making, as well as give a spirit of optimism and confidence in learning activities. This generally facilitates creative abilities and unleashes the personal potential. The article describes the role played by both positive and negative emotions. High concentration of negative emotions erects a communication and sense barrier disturbing sense transaction in learning activities, thus hindering conditions for its development. Defined are positive psychotherapy techniques aimed at the solution of an inner conflict in choice, these techniques are: distancing from the conflict, consideration of the conflict, situational approval, verbalization, enhancement of life goals. The above techniques possess a significant sense potential within the training process in modelling students' axiological choice situations.
\end{abstract}

\section{Introduction}

Since birth, man "specifies" himself through choice, thus defining himself as a personality. In academic activities, sense choice is made with a focus on the construction of one's life combined with the senses of learning contents. Meanwhile the parameters of alternative comparison line up through the lens of the available values and senses. Yet the nature of any choice is as follows: choosing a single alternative from a great number of others we suppress the allure of the rest. So there is an inner struggle of senses, a kind of dualism. Making a choice we always reject something, and aggravating psychological discomfort gives the situation a personal tragic element. Hence tруку are good reasons to apply aspects of the positive psychology concept in modelling axiological choice situations.

The conative component of free choice is actualized within the closing process, which reflects the student's struggle of motives. To solve the conflict of motives, the student applies his inner means and devices of behavior control which he has acquired under the influence

\footnotetext{
*Corresponding author: vim-mir@bk.ru
} 
of adults, peers, due to his own creative discoveries and personal experience. However, there are students who are unable to "actualize" the volitional action closing process themselves. This is a case of a pedagogical goal to deliver "positive" support in decision making, i.e. support in the process of adaptation to new conditions, in the states of uncertainty and in those situations accompanying the above process.

The positive psychology approach enables "to view practically any human behavior, any event as something that might have its positive senses, positive resources for personal growth and development" [1]. W. James wrote that "the greatest discovery of my generation is that man can change his life changing his attitude to it" [2]. B. Fredrickson's theory of positive emotions states that positive experiences produce long-lasting effects and promote personal growth and development. These experiences extend the range of available reflective acts, "cancel" negative emotions, enhance mental resistance to stress factors, create new psychological resources, trigger personal growth mechanisms, "which leads to greater emotional well-being and turns man into 'a better version' of his own self” [3].

The positive psychology approach is rather widely represented in psychological papers, especially in clinical psychology, coaching psychology $[4,5,6,7,8]$. It is stated in pedagogical studies that creation of a "positive medium" is a means that provides conditions for disclosing creative abilities, enhancing engagement in the learning process, disclosing personal potential $[9,10,11,12,13]$. However, there are practically no works on how to create students' axiological choice situations in terms of the positive approach. That is why the objective of this investigation is to define the theoretical and methodological aspects of positive psychology in decision making, based on personal senses.

\section{Materials and Methods}

Positive psychology was created by Martin Seligman, an American psychologist, Director of the Positive Psychology Center at the University of Pennsylvania. Seligman thinks that optimistic people achieve success more often, enjoy good health, are more enduring and robust, live longer, and are sure that their troubles are temporary [7]. They believe that there is always a way out of any difficult situation, whatever choice they face and whatever obstacles they meet they will still move on and finally gain their object.

Positive psychology is based on the theoretical research of humanistic psychology. A. Maslow was the first to use the term "positive psychology" in his book "Motivation and Personality" [14], this term reflecting the idea of using people's potential for their selfactualization and rise in living standards. However, the theoretical research of humanistic psychology never exceeded the level of theoretical ideas. This is precisely why positive psychology gains followers by virtue of the fact that it is based rather upon experiments than hypotheses.

The elementary principle of positive psychology is the transition from the "negative position" to the "positive position", the latter focusing exceptionally on the strong suits and sound functioning of the personality, its aim being "to start catalyzing the shift of the focus of psychology from being concentrated on how to correct bad things in our life to how to construct positive qualities" [15].

It is common knowledge that personality traits influence human behavior, cognition and emotions [16]. The merit of positive psychology is rather in the identification of these traits than in the investigation of how to identify and learn these traits. In other words, the focus is on the personal traits and peculiarities of human behavior which characterize happy people satisfied with their life. M. Seligman [6] replaces the notion of happiness with that of wellbeing whose structure contains more definite measurable components: positive emotions, engagement, sense, achievements and positive attitudes. 
Most papers dedicated to the aspects of positive psychology within the learning process framework, testify that positive traits influence the creative potential of the personality, positive passion helps overcome difficulties, get through uncertainty, besides, to develop creative abilities and disclose personal potential, there should be a "positive" and enabling environment $[9,10,11]$.

The effectiveness of positive psychology in foreign language teaching was pointed out by Lake J. [12]. He stated that positive psychology actualization is beneficial to the level of diligence, self-discipline and engagement in the learning process, which was also confirmed by Japanese students' academic results during their international exams.

There are investigations on the influence produced by positive emotions on decision making and quality of training. Thus, Krashen asserted [13] that high-degree negative emotions entail a filter (his is the notion of an "affective filter") decreasing the volume of intelligible information coming to the student. Contrariwise, in case of positive emotions the "affective filter" is lower and the student is ready to perceive more intelligible information. In our opinion, the "affective filter" in sense theory performs the function of a communicative and sense barrier which disturbs sense transaction in learning activities, thus hindering conditions for the development of personality.

Of interest is B.L. Fredrickson's theory $[17,18]$ based on the investigation of the positive emotions' nature and functions. B.L. Fredrickson comes to a conclusion that positive and negative emotions do not make a dichotomy, neither they are opposites of the same continuum (as was assumed by Krashen's emotions' filter concept), these are rather to be viewed as two experience dimensions. In fact, the function of the positive emotion is essentially different from that of the negative emotion. While negative emotions tend to limit the human attentional field and predispose to definite tendencies to act, positive emotions create tendencies to play and investigate, thus providing broadened attention field and creating resources for future activities.

Among the methods of self-help and psychological support there are those aimed at positive thinking. The latter may develop in case of application of three strategies: positive affirmations, positive passion, positive perception [19]. These methods' targeting is relevant in choice situations. Of special importance is a support of this kind in training primary school students. Thus, positive mindset may be really helpful in getting through the adaptive period [20].

The positive psychotherapy technique proposed by S.A. Vyuzhanina and Ya.S. Suntsova [21] readily fits into the model of students' axiological choice situations. These authors outline five stages of "setting up" for a positive solution of the inner conflict in choice making: distancing from the conflict, consideration of the conflict, situational approval, verbalization, enhancement of life goals.

\section{Results}

The positive psychology concept is based on the three pillars: "a study of positive emotions, generally all those things that make our life 'pleasant': presupposes a need to use one's strong suits for the creation of good living, and the third one (a sensible, valued life): a study of positive phenomena and institutions in the society, which all aid development of best human traits" [5]. The first line is linked with a subjective sensation of happiness (arising positive emotions form feelings of optimism, confidence, "completion", interest in life, strive for success). The second one is dedicated to those individual psychological traits (altruism, empathy, courage, honesty) which favor healthy social environment. This in its turn leads to the possibility of personal advancement and self-actualization.

However, the positive psychology theory fails to adequately disclose the third line linked with sense-making. The mechanism of sense formation, of understanding whether man really 
lives a meaningful life, of whether this life contains meaningful moments, "is still vague", it was later that M. Seligman brought forth the problem of sense adding the thesis on its importance [22, p. 18]. This thesis is based on the commitment to social values: there is a target shift of psychology from egocentrism to philanthropy, from self-fixation to a focus on other people. In this connection, the phenomenon of sense, in his opinion, produces a much greater effect on mental well-being than the emotional state.

In terms of the sense theory this means that in the positive psychology concept the sense of personality becomes a relevant element, while the personality sense often arises in "good", virtuous deeds, which is acknowledged by the author's research [5]. Of certain interest are experimental results stating that those who did "good" deeds to others, as well as made decisions not just in their own favor, but also in favor of the community, were in good spirits afterwards, even enjoyed improved physical activity [5, p. 22-23]. Pious efforts are accompanied by satisfaction, if the choice is governed by pleasure, then there is no point to speak about real sense! Doing good deeds we become happier, and a deed of true kindness does not go together with some expressed emotion like joy. At such moments there is rather complete devotion and self-neglect. These are the minutes which give rise to higher senses prosocial senses characterized by man's inner sense determination to achieve a result that will benefit and do good to other people and the society.

Apparent is the role of positive emotions since they possess a resource for creative activity. And it is evident that negative emotions may alternatively become "noises" in the choice act. Facing a choice full of "negative emotions", life as if stands still, is hindered, blurred is the future event horizon hiding itself behind the choice alternatives. Yet this does not mean that application of negative emotions in modeling axiological choice situations will not inversely create a momentum to activity, since abandoning the comfort zone always favors personality development. That is why positive and negative emotions application is possible within the framework of the choice activity, yet only in accordance with the situation and in a meaningful way. The potential of negative emotions is great in case of the starting point in the sense choice act, while the process itself will naturally be much more effective under a favorable emotional climate in class. For example, a video showing dire fire effects, murder of animals by poachers, etc. may serve as a momentum to the choice of a creative engagement in environmental protection.

To "set up" for a positive solution of the inner conflict in choice making we propose to apply positive psychotherapy techniques involving five stages [21]: distancing from the conflict, consideration of the conflict, situational approval, verbalization, enhancement of life goals.

The initial stage implies a detached view on the conflict. Sometimes a new problem blocks the full view of the event horizon, which is more important to see. Only after the student can see real, not crucial importance, may he start considering the conflict.

Axiological choice always implies a conflict between alternatives bearing definite senses, a conflict of life values. Consideration of the conflict takes course in the direction of four basic spheres: body, sensations ("What are your sensations?"), logic, cognition ("What do you think of the choice?" "Is it a difficult choice?"), personal experience, tradition ("Have you ever come across such a choice?" "What events or feelings is it reminiscent of?" "Have you coped with a choice like this before?"), the future, imagination ("What happens when the problem is not there anymore?").

After the problem has been considered one may resort to situational approval. The client's merits and behavioral patterns are emphasized. The main task here is to reinforce the student's confidence in his ability to manage the situation: now, as he is aware of its content, those actual abilities of his may be developed and become helpful. Interestingly, stories and metaphors are devices of emotional support and behavioral alternativeness recommended by authors in such situations [21]. Once there is confidence in choice making, there starts 
verbalization, i.e. transformation of emotional, unshaped choice content to verbal and logical forms by way of discussing, reasoning over the inner conflict.

After the student has managed to disengage from the conflict (put it into perspective), has considered it (pigeonholed all of its elements), tried to view everything he could in a positive sense, learned to discuss the conflict without excitement, - he proceeds with the finishing level of positive psychotherapy, i.e. enhancement of life goals, which in its turn enhances the sense field, triggers sense creation or transformation of the available senses.

Of course actualization of this technique implies individual work of both the teacher and the student, which gives it the function of a psychological and pedagogical support. Because of this with some disciplines, due to their specificity, this technique is difficult to actualize.

\section{Discussion}

Positive psychology aims to develop instruments for the creation of positive emotions, greater engagement and realization of life purposes. Likewise, in the pedagogical process implementation of positive psychology elements may create students' psychological wellbeing, make them find positive emotions in their studies, help cope with adaptation, failures, mistakes, assist in their choice while getting through the inner conflict, remove communicative and sense barriers that promote deterioration of sense and creative activities.

According to M. Seligman, those deeds aimed at doing good to other people bring positive passion, give true joy and saturate life with senses! Accent upon pious efforts or mutual aid among students may be actualized during various kinds of creative engagement, project activities. As an example, in learning the discipline "The World Around" students may choose projects like "Let's Save the Forest All Together", "Down with Garbage", etc.

High concentration of negative emotions gives rise to the communication and sense barrier ("affective filter"), the latter disturbing sense transaction in learning activities and thus hampering conditions for personality development. However, few or low-concentration negative emotions might give rise to a sense and creative activity, especially in the starting point of the choice act. Hence positive and negative emotion application must depend on the situation and aim of the learning activity.

One may raise the level of satisfaction with one's deeds, improve the quality component of choice in case one applies the methods of positive thinking. These imply application of psychological attitudes in decision making, i.e. persuasive statements with an accent upon a wish to possess something (abilities, skills, traits, attitudes), positive mindset - inner belief in one's own possibilities and success in one's undertakings, as well as formation of positive perception, description of reality through the lens of the available resources and possibilities [19].

Of special value are positive psychotherapy techniques aimed at the solution of the inner conflict during choice: distancing from the conflict, consideration of the conflict, situational approval, verbalization, enhancement of life goals. All these techniques have a significant sense potential within the framework of the learning process in modelling situations of the students' value and sense choice.

\section{Conclusions}

Inclusion of positive psychology elements in modelling situations of the value and sense choice seems necessary in case of the act of choice, which is always based on some tragedy, sacrifice. Positive psychology technologies and strategies are aimed at support and help in coping with the inner conflict, inner experience lying behind alternativeness of choice. 


\section{References}

1. S. Elshansky, O. Efimova, M. Kovineva, Perspektivy pozitivnoy psikhologii v Rossii. Sovremennye nauchnye issledovaniya innovatsii http://web.snauka.ru/issues/2016/11/71993

2. T. Batler-Boudon, 50 knig i velikikh idey, kotorye pomogut vam izmenit' svoyu zhizn' (“Astrel"', Moskva, 2006)

3. I. Bonivell, Klyuchi k blagopoluchiyu: chto mozhet pozitivnaya psikhologiya ("Vremya", Moskva, 2009)

4. C. Kauffman, Positive Psychology: The Science at the Heart of Coaching (John Wiley, Hoboken, N.J., 2006)

5. M. Seligman, Novaya pozitivnaya psikhologiya: Nauchnyi vzglyad na schastye $i$ smysl zhizni (Izdatel'stvo "Sofiya", Moskva, 2006)

6. M. Seligman, Flourish: A visionary new understanding of happiness and well-being (Free Press, N.Y., 2011)

7. M. Seligman, Kak nauchit'sya optimizmu (Al'pina Publisher, Moskva, 2017)

8. S. Green, S. Palmer, Positive Psychology Coaching in Practice (Routledge, New York, 2019)

9. C.R. Snyder, Journal of Counseling and Development 73, 355-360 (1995)

10. C.R. Snyder, H.S. Shorey, J.S. Cheavens, K.M. Pulvers, Journal of Educational Psychology 94(4), 820-826 (2002)

11. S. Li, Y. Lin, Ch. Lu, R. Chung, D. Chen, J. Chen, W. Chou, Advances in Education Sciences. 3-rd International Conference on Creative Education (Kuala Lumpur, Malaysia, 2017).

12. J. Lake, Language learning motivation in Japan (Multilingual Matters, Bristol, 2013)

13. S.D. Krashen, The input hypothesis: Issues and implications (Longman, New York, 1985)

14. A. Maslow, Motivation and personality (Wiley, NY, 1954)

15. D. Leont'ev, Psikhologiya. Zhurnal Vysshey shkoly ekonomiki 4(9), 36-58 (2012)

16. G. Matthews, I. Deary, M. Whiteman, Personality Trait (Cambridge University, Cambridge, 2009)

17. B.L. Fredrickson, American Psychologist 56, 218-226 (2001)

18. B.L. Fredrickson, American Scientist 91, 330-335 (2003)

19. V.Yu. Slabinsky, Meditsinskaya psikhologiya v Rossii 6(29) http://mprj.ru, lastaccessed 2020/08/31

20. S.D. Dyatlova, I.I. Kirichenko, L.A. Savinkov, O.G. Khlopovskikh Sibirskiy pedagogicheskiy zhurnal 1, 103-110 (2012)

21. S.A. Vyuzhanina, Ya.S. Suntsova, Pozitivnoe napravlenie $v$ konsul'tirovanii $i$ psikhoterapii (Izdatel'skiy tsentr "Udmurtskiy universitet", Izhevsk, 2018)

22. M. Seligman, Flourishing: positive psychology and the life well-lived (American Psychological Association, Washington (DC), 2003) 